\title{
WEAVING IN ANATOLIA ON THE TRAILS OF THE HITTITE CIVILIZATION Özlem KAYA
}

\author{
Dr. Öğr. Üyesi, Hitit Üniversitesi, Güzel Sanatlar, Tasarim ve Mimarlık Fakültesi, \\ dr.ozlemky(at)gmail.com \\ $\ddot{O Z Z}$
}

\section{Anahtar kelimeler: Weaving Hittites}

The Hittite economic system, Hittite social life

Anatolia occupies a separate and special place for those studying the history of the world. It has always been a precious living space influencing the cultures around it and being settled as a homeland. Since the Paleolithic, Anatolia has been home to the great civilizations. Accordingly, it can be seen that this geography has a multinational and multilingual structure. Besides, it has been a place on which a lot of civilizations thrived thanks to its geographical location and its importance in terms of economy, and the fact that the roads directing the world trade were both on it and near it. One of the most important of these civilizations is the Hittites, which has a special place in the history of Anatolia. The Hittite Empire, which represents a great civilization in Anatolia, created important artistic works and also established strong commercial relationships during the period in which they ruled over Anatolia. It is possible to say that the Hittites formed their economic and social systems in a way that they could meet the requirements of the central administration.Having emerged and afterwards founded a civilization in Anatolia, the Hittites rank first among the most known and conspicuous civilizations. They played a very crucial role by forming an extremely important civilization in the history of Anatolia. In this regard, it can be stated that the Hittites led the other states in the way of civilization, in political, economic and social terms. We can say that they had a very developed society especially in terms of economics and they had a unique economic lifestyle.

\section{HITTITT UYGARLIĞI İZINNDE ANADOLU’DA DOKUMACILIK}

\begin{abstract}
Anadolu, dünya tarihini inceleyenler için ayrı ve özel bir yere sahiptir. Anadolu her zaman çevresindeki kültürleri etkileyen, yerleşilen, yurt edinilen değerli bir yaşam alanıdır. Eski Taş Çă̆ı'ndan beri Anadolu büyük uygarlıkların yurdu olmuştur. Bu nedenle bu coğrafyanın çok kavimli ve çok dilli bir yapısı olduğu görülmektedir. Aynı zamanda coğrafi konumu ve ekonomik yönden taşıdığı önem ve dünya ticaretini düzenleyen yolların hem yakınında hem de bu yolların üzerinde bulunması sebebiyle birçok uygarlığın geliştiği bir bölge olmuştur. Bu uygarlıklardan en önemlilerinden biri de Anadolu tarihi içerisinde özel bir yere sahip olan Hitit uygarlığıdır. Anadolu' da büyük bir uygarlığın temsilcisi olan Hitit Devleti hakim oldukları zaman dilimi içerisinde önemli sanat eserleri yaratmış aynı zamanda güçlü ticari ilişkiler kurmuşlardır. Hititlerin ekonomik ve sosyal sistemlerini, merkezi yönetimin gereklerini yerine getirecek biçimde kurduklarını söylemek mümkündür. Anadolu' da kurulup büyük bir medeniyet kuran Hititler, en bilinen ve en dikkat çekenlerin başında gelmektedir. Hititler, tarihte çok önemli roller üstlenmiş olup, Anadolu tarihinde çok önemli bir medeniyeti oluşturmuşlardır. Bu bağlamda Hititlerin siyasi, iktisadi ve sosyal anlamda diğer devletlere medeni öncülük ettiği söylenebilir. Özellikle iktisadi anlamda çok gelişmiş bir topluluk olduğu ve kendilerine has iktisadi bir yaşam tarzlarının olduğunu söyleyebiliriz.
\end{abstract}

Keywords:

Dokumacilik,

Hititler,

Hititekonomik

sistemi,

Hitit sosyal hayat 


\section{Introduction}

Anatolia experienced one of its brightest and most vivid periods with advent of, even for a short period, the Mesopotamian cuneiform system to the place about 4000 years ago. Assyrian merchants, who settled on the south and south-east parts of the naturally sourceful Middle Anatolia with the hopes of establishing commercial affairs based on bartering with the local Anatolian people in around 1900 BC, introduced new dimensions to the economic and cultural life in the Ancient Anatolia and, most importantly, established large scale commercial colony centers. Assyrians brought primarily weaving products and tin to Anatolia, and in turn got raw mines.

It is possible to say that not many radical changes exist between the modern times and the First Age societies, in terms of wage-labor relations in the production relationships in Anatolia. The wages of qualified and other kinds of people were signified by law. Also, the price that a person who bought (employed as a worker) anybody among potters, craftsmen, hammer smiths, carpenters, leathermen, carpet makers, weavers or dress producers had to pay was ten silver shekels.

During these times when there were intimate commercial relationships in Middle Anatolia, the Hittites started to migrate towards Anatolia. In about 1750 BC, 100 years after the commercial activities of the Assyrians weakened in Anatolia, the Hittites engaged in commercial activities along with the things they learnt and benefited from intimate commercial relationships that they witnessed (Ünal, 2017; Martino, 2014; Süel 2008).

"The Land of Hatti", the center of the Hittite Kingdom which turned into an empire by carrying its affective parts as far as Mesopotamian borders and thus appeared on the stage of history in Middle Anatolia, was founded by kings who maintained their reigns over these mountainous regions (Bryce, 2003: 20).

The Hittites created a high-level civilization that was unique and unparalleled in the Near East in spite of intimate effects of Hatti, Mesopotamia and the Hurrians (Akurgal, 1995: 75).
Representing a great civilization in Anatolia, the Hittite Empire dominated the political fate of Anatolia between 1700 BC and 1200 BC. Ruling over Anatolia for long years, just as they had their unique language, laws, religion, art and trades, the Hittites also had unique production methods.

The Hittites started the process of establishing a central state in Anatolia, which had a particularistic structure formed by city-states, by making Hattusa (today Boğazköy in Corum Province) their capital. Social and economic systems were founded so that they would meet the necessities of a central state. The traditions and methods of the Hattians, which formed the majority of locals, guided the Hittites.

As per the country's conditions, the economy of the Hittites relied on agriculture. But, there were also people having craftsmanship in various fields in the Hittite society other than the farmers responsible for the cultivation of the soil. There are evidences especially for the existence of weavers, doctors, carpenters, stone masons, potters, shoemakers, tailors, barkeepers (male and female), fishermen, chefs, gatekeepers and wardens who spent their labor force for the palace and the temples (Macqueen, 1996; Sevinç, 2008). Especially the Hittite women engaged in milling, cookery, weaving and carpet making, apart from their activities inside the house. There is also information on the Hittite documents regarding the women engaging in weaving. It is understood from the ritual and festive texts that these women engaged in weaving not merely to meet the requirements of the house, but actually professionally (Süel, 1990; Yiğit, 2002). In this context, the objective in this study is to determine the place of weaving in the Hittites' every day and social lives. In accordance with this objective, the study also includes the assessments of the benefits of the weavers on the production and how they occupied a space in the Hittite economic system.

\section{Weaving in Anatolia}

Human beings started to make the soil efficient and grow plants by adopting a sedentary life. From fiber they created threads, and from threads they created 
weaving. Therefore, they experienced a great development by discovering weaving, the first production. The archaeological findings found with regards to the start of the weaving enhance the information on the history of humanity. Because the development level of weaving is directly proportional to the structure of a particular society.

The archaeological findings on weaving in Anatolia reveal that weaving showed regular developments and form the information on the beginning of humanity. Anatolia, the cradle of civilizations, has a fundamental and common weaving culture bearing the traces of all the civilizations from past to present.

Having started as a direction towards the meeting of the individual requirements, the activity of weaving occupied a crucial place in the financial income indicators of the Mesopotamian, Egyptian, Anatolian and Aegean societies during the Bronze Age. It is especially understood, from the texts belonging to the period, that the weaving sector had an active role in both the domestic and the foreign trade dynamism of these regions. The reflection of the culture of the societies on dresses, the usage of textile products in various fields of everyday life, and the occurrence of social stratification and class division increased the variety of weaving in the fields of clothing and textile decoration (Gül, 2017).

Though the studies done on textile in Anatolia are limited, especially the studies done in Çatalhöyük are well worth the attention. The weaving samples found in the excavations that Mellaart had carried out in Çatalhöyük in 1962 can be considered a proof for the view that Anatolia was the starting point of textile (Mellaart, 1962). Besides, the weaving pieces belonging to the Neolithic that were obtained from the excavations reveal that the history of weaving is very ancient in Anatolia. This event situates the beginning of the weaving in the world beyond estimated (MEB, 2012).

Anatolia has an important part in the history of the clothing in the world. Also, when evaluated in terms of weaving and the traditional apparel culture, it occurred and developed as a result of the interaction between various nations from Europe, Africa, Middle East and Middle Asia, culminating in a richness with regards to diversity.

Upon going as far back in Anatolia as the Neolithic, it can be seen on a lot of documents and sources that the practice of weaving was done as a profession and the weavers professed this especially in cities. Considering that the daily needs were met mostly inside the house due to the conditions of the period, weaving must have been carried out, albeit in a small-scale way, in the ateliers inside the houses.

Weaving is an indispensible part of everyday life for both the production of clothing and the basic home textile. As especially can be seen in other crafts, the production aimed at the market needs in the craft of weaving came to the forefront by following the economic development process, exceeding the house and family borders with the advent of the market needs, that is, leaving behind the home industry and closed home economy periods, and have survived until today by passing through several stages.

\section{Weaving in the Hittites}

The first information on the presence of the Hittites in Anatolia can be traced back to the Kültepe and Assur cuneiforms (Martino, 2014: 32).

The Hittites established a great civilization by settling in Middle Anatolia in $2000 \mathrm{BC}$ and expanding through the whole region between 1800 BC and 1200 BC. The Hittites had strong commercial relationships Mesopotamia. The tradings of textile and precious mines between the Assyrians and the Hittites can be seen in various cuneiforms (Türkoğlu, 2002).

It is seen that the Hittites became dominant in Anatolia after the Assyrian Trade Colonies period. Mutual relations and interactions in such subjects as apparel were experienced thanks to the close political and social relationships established with Northern Mesopotamia, Syria and Egypt, in different stages of the Hittites history. Based on the artistic works of the Hittites period like rock monuments, figurines, statuettes, seals or seal 
impressions and cult vases, and the information from written documents, we can say that the apparel of the Anatolian society showed extremely plain and unique characteristics during this period. It catches the attention that on the written and visual materials that give information on the apparel in the Hittites period, mainly important people like the king and the queen, officers and reverends, or officials such as acrobats, musicians and servants were included (Türkoğlu, 2002). It can be understood from the written and visual sources that the clothes were combined with various accessories and were colored differently and in accordance with each part (Darga, 2013). The Vases of Inandık (Özgüç, 2006) and Hüseyindede, belonging to the ancient Hittites period, give extremely important information on the colors and shapes of the clothes (Sipahi, 2000; Yıldırım, 2005) (Figure 1-3). Based on the depictions on these vases, it is possible to obtain information on which colors were used on the clothes of this period, what kind of characteristics and shapes the clothes had, and therefore, the weaving methods utilized.

Vases of Hüseyindede 4. Frieze

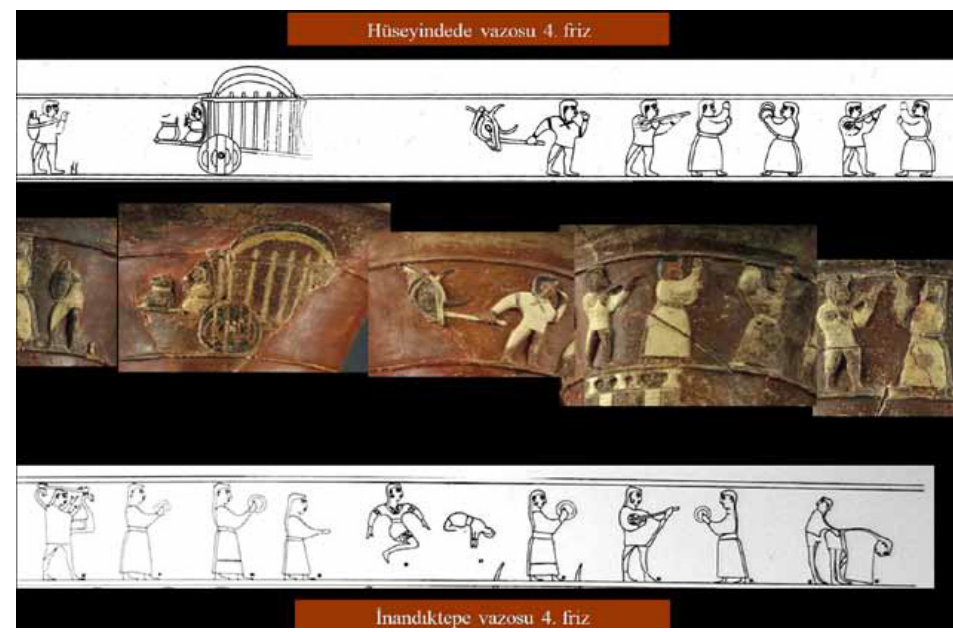

Vases of İnandik 4. Frieze

Figure 1- Figures on the Uppermost Frieze of the Vase (4. Frieze)

(Y1ldırım, 2013: 92)

The majority of the clothes mentioned in the texts of the Hittites period belonged to the males. Information on the clothes of the females are limited. Nevertheless, a great deal of data and view hold that the clothes of the Hittite women were extremely plain and low-key, compared to the female clothes of Mesopotamia, Egypt and Crete societies. In a text that gives information on the female clothes, the descriptions "A dress pulled upwards, a studded tunic, a cloak, a headdress, an undergarment, a set of belted tunic, a set of silver belted tunic, a set of breast ornaments made of silver all belonged to women" are found (Darga, 2013). When looking at the distinct clothes of the males on the Hittite sculptures and reliefs, their pointed cones unique to gods carried on heads, their short skirts made with diversely patterned weavings, and their round-ended buckle belts catch one's attention (Türkoğlu, 2002).

With Middle Bronze Age, weaving became industrialized in Anatolia and surrounding regions. The fact that in the early Hittite Empire period the weaving loom weights no longer had the same form diversity as 3000 BC and started to be produced in a certain size and form is a proof of this (Fazlıoglu, 1997). Also, one of the four differently-represented types of weaving loom weights was "crescent-shaped loom weights", famous in the Hittites culture region. The usage of such loom weights on the Hittite period layers in settlements like Alacahöyük and Boğazköy indicates the importance of weaving in these places. The extensive utilization of such looms has led them to be known as "Hittite loom weights" in literature (Dönmez, 2010; Yılmaz, 2016).

Besides, there was a distinct law for weavers in the Hittite legislation, and this shows the influence of the weaving on the empire. The Hittites practiced the weaving profession in villages and especially in the winter seasons. It is also known that this profession was generally practiced by women belonging to various profession groups such as "Munustúg" (female tailor), or "Munusuš Bar" (female weaver).

The government specified the prices for the fabric and clothes. The diversity in fabric and clothes is a proof that the Hittites produced diversely-qualified properties with diverse raw materials (Gül, 2017; Alparslan, 2013).

The Hittite legislation was created meticulously in order to protect the Hittite society against all kinds of unjust treatment they were exposed to. This meticulousness also showed itself in weaving. Some privileges were given to the weavers during this period. For ex- 
ample, the weavers in the city of Arinna were exempted from "šahhan" and "luzzi" liabilities which were basically land obligations. This exemption was also present for the weavers in the city of Zippalanda. These weavers were probably commissioned in the temples, and therefore had some privileges. The dedication of these two cities in question to the two god-leaders of the Hittite pantheon confirms this conclusion (Imparati, 1992).

Arinna and Zippalanda held privileged places since they were the cities coming to the forefront in the weaving sector, besides each being a sacred city. It was clearly signified in the legislations that the houses and the land of the weaver in Arinna and Zippalanda were exempted (Ünal, 1999).

Although the clothing pieces among the works that have survived from the ancient times until today are very little in number and torn in appearance, the ornaments used in ceramic forms, sculptures, frescoes and murals reflect the apparel characteristics, weaving characteristics and the changing approaches of periods and societies; also, information on the male-female apparel and the weaving characteristics of this culture (Figure 2) can be obtained from a lot of stone reliefs, bronze statuettes, vase images and written cuneiforms belonging to the Hittites (Köhler, 1963; Yıldız, 1993).
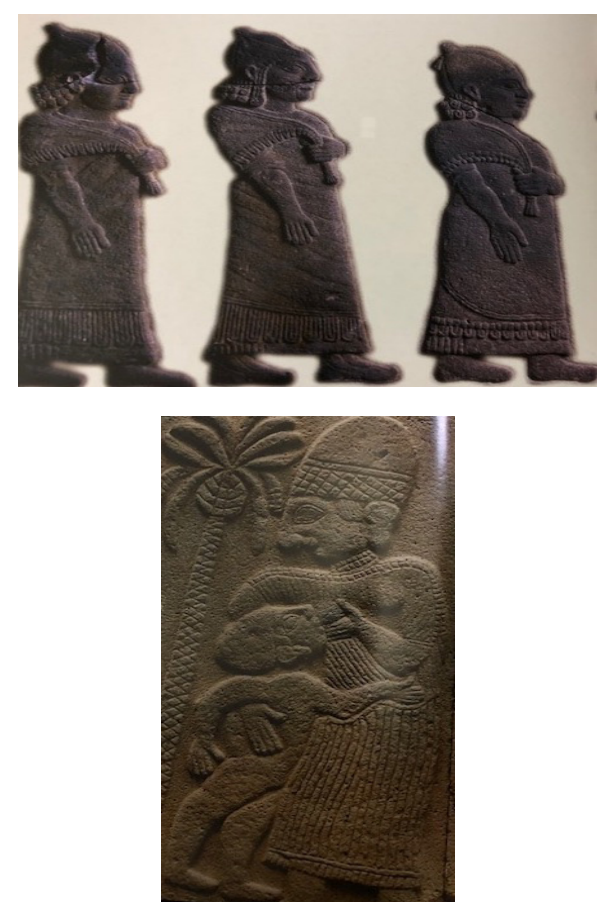

Figure 2- The Late Hittite Period, $8^{\text {th }}$ Century BC (Anonym, 2011)
On a pot belonging to the Ancient Hittite Period, male and female figures are found to have been depicted with long and large clothes covering the whole body (Darga, 1993). However, in the examples belonging to the Late Hittite Period, round-neck, armless and plain clothes extending to the ground can be found on the couples depicted on reliefs made on big basaltic blocks (Darga, 1992).

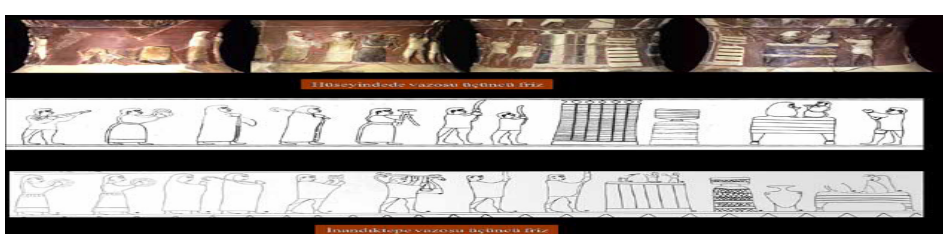

Vases of Hüseyindede 3. Frieze

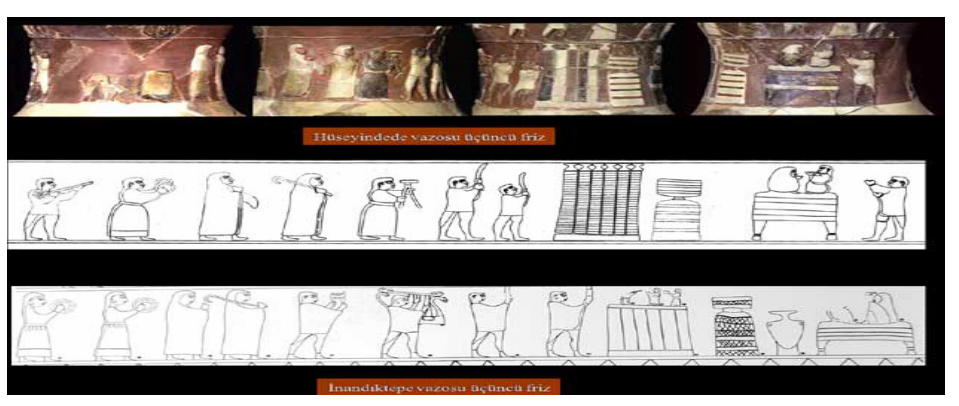

Vases of İnandık 3. Frieze

Figure 3- 3. Frieze (Comprising the Largest and the Most Flamboyant Part of the Vase) (Yıldirım, 2013: 90)

Long sleeve and diagonally-plaited clothes extending to the ankles, tight on the waist and below, and completely fit on the upper parts, set the ground for the Hittite women's clothing. On some depictions found in Yazılıkaya, these long clothes enabled the body lines of the women to be revealed, since they were tightened with a belt on the waist. The women that were depicted on the vase found in Inandik (near present-day Cankırı) also had the same style clothes (Türkoğlu, 2002). On the other hand, it is possible to see on some male statuettes that there were sashes made with the method of weaving or the knotting technique on male clothes (Yildiz, 1990).

Two materials that show the need for and the dimension of the weaving in the Hittite economy were wool that was colored differently and had a place among the materials used in rituals, and the clothes that showed great diversity in religious ceremonies and especially www.idildergisi.com 
festival rituals.

It is especially known that the women engaged in the commercial life actively, did business on their own, and ordered weaving on behalf of themselves. The price ranges of the clothes or weavings that they traded were diverse. As seen in Table 1, Túg Sig (a precious cloth) ranked as the most expensive cloth, worth 30 shekels of silver (The Hittite Laws). We can say that the way it is described as a precious cloth correlated with its price being higher than the other clothes.

Table 1- Various Prices of Clothes and Weavings in the Hittites

\begin{tabular}{ll}
\hline Product Name & Price \\
\hline I TƯG happuššant "1 hapuššant & 12 shekels of silver \\
cloth"
\end{tabular}

I TÚG.SÍG “1 precious cloth” 30 shekels of silver

ITÚG.SIGZA.GÌN “1 blue-wool- 20 shekels of silver en cloth"

\begin{tabular}{|c|c|}
\hline I TưGADUPLI “1 cloak?” & 10 shekels of silver \\
\hline $\begin{array}{l}\text { I TÚG }{ }_{\text {iškališšar }}{ }^{24} \text { “1 iškališšar } \\
\text { cloth” }\end{array}$ & 3 shekels of silver \\
\hline I TUUG IM.K[I?] “1 IM.KI. cloth” & 4 shekels of silver \\
\hline $\begin{array}{l}\text { I TÚG } \\
\text { coarse fabric" }\end{array}$ & 1 shekels \\
\hline
\end{tabular}

I TÚG.GU.È.A SIG "1 thin shirt” 3 shekels of silver

I TÚG.GÚ “1 shirt” $\quad X$ shekels of silver

I TÚG 7 MA.NA KI.LÁ.BI “a X shekels of silver cloth weighing 7 minas"

I GADA GAL "1 large canvas" 5 shekels of silver

TÚG hapušant - a piece of cloth, TÚG hapušant / hapušant - a cloth

TÚG ${ }_{\text {iškališšar ( }}$ TÚG iškalleššar) - a slit cloth, TÚG $_{\text {iškal- }}$ leššar / iškalliššar - a back vent cloth (Ünal, 2007: 273, The Hittite Laws, Imparati 1992)

The Hittites' domination over the trade roads in the region, seizure of the new trade routes and achievement of a great economic power (especially through taxes including those of textile and wool (Beckman, 1992: 44)) affected the development of weaving and formed a serious basis for it to survive until today, besides also affecting various other fields.

\section{Conclusion}

The industry of weaving plays the important roles of starting and exit points for industrialization in terms of developing countries, thanks to its being a labor-intensive industry field and its having a crucial role in production and export. In addition, this industry field is accepted as a tool for developing countries to open their economies to foreign markets. Because, the weaving industry labor force is regarded as a leading sector in terms of industrialization and progress in developing countries, due to having a set of advantages such as raw material. A complete industrial infrastructure and a deep-rooted history have especially vital roles in the prominence and development of this industry in developing countries.

Weaving itself and weaving tools present important data with regards to the history of weaving in Anatolia. It is known that there were structures used as weaving ateliers in either in a room of or outside the houses in a lot of regions in Anatolia, dating back to 2000 BC. Besides, the existence of weaving loom weights uniquely used in this region (crescent-shaped loom weights famous in the Hittite culture region) is an exact proof that weaving was central in this geography.

Also, when considering the characteristics of apparel during the period, it is possible to obtain information on the utilization methods of the pieces, accessories and weaving characteristics used in female and male depictions examined. The fact that some characteristics and utilization methods examined in some depictions belonging to the Hittite period are still being used today in the same Anatolian geography is well worth the attention (The method of rubbing the ends of the headscarf in a waist accessory, the tradition of large sashes, and accessories reminiscent of breechcloths or back sashes for waist are still alive thanks to the present-day Anatolian women).

Weaving is one of the indispensible elements for human life. Since the ancient times, women especially have been depicted as either spinning yards with spinners and loom weights, or weaving in front of weaving 
looms, on visual materials. Found during the archaeological excavations in Alacahöyük, one of the central places in the Hittite Kingdom, the presence of loom weights inside female graves in comparison to male ones which contained lined-up weapons on the knees, and spinners frequently depicted on the headstones belonging to the Late Hittite period all show that weaving indeed was a crucial factor for women.

Archaeological and philological studies done until today have enabled information on weaving, and therefore on the apparel of the period, to increase. In this context, this study, continuing studies and forthcoming works will enable information on weaving to be enriched more and present substantial data to the future generations.

\section{References}

Alparslan D. M., Hititlerde kadın. Aktüel Arkeoloji 70, 2013.

Akurgal E., Hatti ve Hitit uygarlıkları. İzmir: Yaşar Eğitim ve Kültür Vakfı, ISBN:975-95024-0-2, 1995.

Anonym, Hitit-Geç Hitit yerleşimleri anıtlar müzeler. İstanbul: Uranus Yayıncilık, 2011.

Beckman M. G., Hittite administration in Syria in the light of the textes from Hattuša, Ugarit and Emar. Bibliotheca Mesopotamica 25, New Horizons in the Study of Ancient Syria, (Eds. M. W. Chavalos-J. C. V. Hayes): 41-49, 1992.

Bryce T., Hitit dünyasında yaşam ve toplum. Ankara: Dost Kitabevi Yayınları, 2003.

Darga A. M., Hitit sanatı. İstanbul: Akbank Kültür ve Sanat Kitaplar1, 56: 315, 1992.

Darga A. M., Anadolu tarihi çağlarında kadın, çağlar boyu Anadolu'da kadın. İstanbul: Kültür Bakanlığı, 1993.

Darga A. M. Anadolu'da kadın, (on bin yıldır eş, anne, tüccar, kraliçe). İstanbul: Yapı Kredi Yayınları, 2013.

Dönmez Ş., Dönmez Naza, E. E., Oluz Höyük 2007 yılı çalışmaları. Ed. Ş. Dönmez. Ankara: Kašku Ülkesi'nin Önemli Kenti Amasya-Oluz Höyük 2007 ve 2008 Dönemi Çalışmaları Genel Değerlendirmeler ve Sonuçlar: 21-33, 2010.

Fazlıŏ̆lu İ., Eski çağda dokuma. İstanbul: Eskiçağ Bilimleri Enstitüsü Yayınları, 1997.
Imparati F., Hitit yasaları, Ankara: İtalyan kültür heyeti. Aktaran, Esma Reyhan, "Hititlerde Gündelik Hayata Dair İktisadi İlişkiler". dergiler.ankara.edu.tr., 1992.

Köhler C. A., History of costume. New York: Dover Publications, 1963.

Macqueen J. G., The Hittites: and their Contemporaries in Asia Minor (Ancient Peoples and Places). London, 1996.

Martino S. D., Hititler. Ankara: Dost Kitabevi Yayınlar1, 2014.

MEB, Geleneksel Türk dokuma sanatları. Ankara: El Sanatları Teknolojisi, T.C. Milli Eğitim Bakanlığı, 2012.

Mellaart J., Excavations at Çatal Hüyük. AnSt-12, Journal of the British Enstitute of Archaeology at Ankara, 1962.

Özgüç N., Kültepe kaniš / neša yerli peruwa ve ašur-1mitti'nin oğlu Assur'lu tüccar uşur-sa-ıstar'ın arşivlerine ait kil zarfların mühür baskıları. Ankara: Türk Tarih Kurumu Yayınları, 2006.

Sevinç F., Hititlerin Anadolu'da kurdukları ekonomik ve sosyal sistem. SDÜ Fen Edebiyat Fakültesi Sosyal Bilimler Dergisi 17, pp. 11-32, 2008.

Sipahi İ. T., Eine althethitische reliefvase vom Hüseyindede tepesi. İstanbuller Mitteilungen: 63-85, 2000.

Süel A., Belgelere göre Hitit tapmaklarn nasıl korunuyordu? X. Türk Tarih Kongresi, 11, Ankara: TTK Kurumu Yayınlar1, ss. 25-27, 1990.

Süel M., Bir Hitit başkenti Ortaköy Şapinuva. Ankara, 2008.

Tutuk G. G., Anadolu'da arkeolojik ve filolojik veriler 1şı̆̆ında tekstil teknolojisinin gelişimi (M.Ö. 3000 sonlarina dek)". http:/ / www.academia.edu/10877587 (Erişim Tarihi:10.12.2017), 2017.

Türkoğlu S., Tarih boyunca Anadolu'da giyim kuşam. İstanbul, 2002.

Ünal A., Hitit metinlerinde eski Asur ticaret kolonileri çağıyla ilgili kayıt ve anımsamalar. dergiler.ankara. edu.tr (Erişim Tarihi: 10.12.2017), 2017.

Ünal A., Hititler-Etiler ve Anadolu uygarlıkları. Ankara: Etibank Yayınları, 1999.

Yildırım T., Hüseyindede tepesinde bulunan yeni bir kült vazosu. V. Uluslararası Hititoloji Kongresi Bildirileri: 761-779, 2005.

Yıldırım T., Hüseyindede kazısı ve eski Hitit sana- 
tına katkıları. Çorum Kültür Sanat. Bilim, Kültür, Sanat, Tarih ve Turizm Dergisi 14, ss. 78-92, 2013.

Yıldız N., Bozkırda deri sanatı, atlı kavimlere ait deri buluntular. Sanat Tarihi Araştırmaları Dergisi 3, 3, 7 : 43-51, 1990.

Yıldız N., Eskiçağda deri kullanımı ve teknolojisi. İstanbul: Marmara Üniversitesi Yayın No: 540, 1993.

Yılmaz D., Geç Tunç Çağı'nda Batı Anadolu'da tekstil üretimi: Çine-Tepecik Höyüğü tezgâh ağırlıkları". TÜBA-AR 19, 2016.

Yiğit T., Hititçe çivi yazılı metinlerinde dokumacılar. Tarih Incelemeleri Dergisi 17 (2): 79-84, 2002. 